\title{
The Effect of Value and Reference Group on Young Consumer's Hedonic Buying
}

\author{
Diana Hartatin* \\ Department of Family and Consumer Sciences, \\ Faculty of Human Ecology, \\ Bogor Agricultural University
}

\author{
Megawati Simanjuntak \\ Department of Family and Consumer Sciences, \\ Faculty of Human Ecology, \\ Bogor Agricultural University
}

*Corresponding author: hartatin.diana@yahoo.com

\begin{abstract}
Hedonic buying is one of buying behavior that based on happiness aspect, involved sensory and excluded needs. Hedonic buying can cause individual to be extravagant in long term period. The aim of this research was to analyze the effect of value and reference group on young consumer's hedonic buying. The design of this research was cross sectional study with survey method answered by self-report questionnaire. The results were supported by an in-depth interview with some samples. This research involved 205 undergraduate students of Bogor Agricultural University which were selected by using proportional random sampling. Statistical analysis used in this study was independent t-test and multiple regression analysis. There was a significant difference on excitement value dimension and hedonic buying between man and woman. The variable of value had significant and positive influence on hedonic buying, meanwhile reference group did not influence significantly on hedonic buying.
\end{abstract}

Keywords: hedonic buying, reference group, value

\begin{abstract}
Abstrak. Pembelian hedonis merupakan suatu pembelian yang berdasarkan pada aspek kesenangan, melibatkan sensori dan diluar kebutuhan. Pembelian hedonis dalam jangka waktu panjang menyebabkan individu menjadi boros. Tujuan dari penelitian ini adalah menganalisis pengaruh nilai dan kelompok acuan terhadap pembelian hedonis konsumen muda. Desain penelitian ini menggunakan cross sectional study dengan metode survei secara self-report menggunakan kuisioner. Hasil penelitian didukung dengan wawancara mendalam terhadap beberapa contoh. Penelitian ini melibatkan 205 orang mahasiswa Strata-1 (S1) Institut Pertanian Bogor yang dipilih secara proportional random sampling. Analisis statistik yang digunakan adalah uji beda independent t-test dan analisis linear berganda. Terdapat perbedaan signifikan pada dimensi nilai kegembiraan dan pembelian hedonis antara laki-laki dan perempuan. Nilai berpengaruh secara signifikan dan positif terhadap pembelian hedonis, sedangkan kelompok acuan tidak berpengaruh signifikan terhadap pembelian hedonis.
\end{abstract}

Kata kunci: kelompok acuan, nilai, pembelian hedonis 


\section{Introduction}

Hedonic buying is one of buying activity include emotional aspect and high involvement (Sarkar, 2011) and it is also reflected with buying behavior that involved multisensory, fantasy, and experience aspects which is involved emotion of consumer toward a product (Alba and Williams, 2012). A young age individual has more negative emotions, and according to Carstensen, Gross, Skorpen, Tsai, and Hsu (1997), they are more expressive to show negative emotions than older people who have better control of emotions. Therefore, young consumer has more chance to do hedonic buying. According to Luo and James (2013), hedonic buying is caused by many factors, either internal or external factors.

One of internal factor that influences hedonic buying is value that is important for individual or society and becomes base of individual behavior (Dewantara and Simanjuntak, 2014). Value is something that is important for a person or group of people who can steer a person's behavior (Mahdi, 2014). One of behavior forms done by a consumer is purchasing (Sumarwan, 2011). According to Escalas and Bettman (2003), reference group is social group which is important for consumer and as comparator to themselves. According to Permatahati (2013), reference group is the external factors that influence purchases.

Buying activity cannot be separated from needs and desires in accomplishment due to different encouragement of each individual. Need is psychological aspect that must be filled to be able to do activity and become base of individual to do an effort (Nurjanah, 2010), while desire has goal to get sheer pleasure and it called hedonic and in long term can cause extravagant or consumptive impact (Pinasthika, 2010). Commonly, desire and need have almost the same meaning that makes confusion in daily buying activity that leads to hedonic buying. The high emotions involvement from younger consumers is expected shown in hedonic buying. Therefore, it is important to know the factors that cause hedonic buying on young consumer that have negative effect in long term. This research aims to analyze the effect of value and reference group on hedonic buying through: 1) identifying the difference of value, reference group, and hedonic buying of young consumers based on gender; and 2) analyzing the effect of value and reference group on hedonic buying of young consumer.

\section{Literature Review}

According to Alba and Williams (2012), consumer's hedonic behavior is reflected by behavior that realizes individual multisensory, fantasy, and emotion experience aspect toward a product. The things that influence individual to form hedonic behavior are individual goal, individual pleasure expected which is categorized into two groups: pleasure over product quality and pleasure over self-experience, selfcontrol, and other aspects. Sarkar (2011) claimed that hedonic buying which involved emotional aspect and high involvement can also require two aspects namely physiological and psychological aspects. Physiological is characterized by high involvement in the purchase of a product, while psychological is marked with the encouragement of the self as internal factors that give the power to someone in the purchase. The study of Veenhoven (2003) has two points of view on hedonic buying, that is nation-level hedonic and individual-level hedonic. The result of the research 
shows that nation-level hedonic had positive correlation with accepted moral happiness and active recreation, meanwhile individual-level hedonic had correlation with attitude and hedonic action itself.

Pattipeilohy, Rofiaty, and Idrus (2013) concluded that one of the factors that create hedonic consumption is situational factor or money and time availability. Guler (2014) claimed that some individual values could influence individual hedonic consumption. Hedonic consumption dimensions consist of excitement and run away dimension, innovation, happiness and enjoyment, meanwhile individual values can be categorized into ten groups that can influence hedonic consumption. They are virtue value, universal, self-direction, suitability, tradition, power, self-security, spirituality, stimulus, and hedonism.

Patel and Sharma (2009) revealed that consumers had two buying motivation, they are utilitarian buying motivation and hedonic buying motivation. Utilitarian buying motivation consist of buying comfort dimension, economic buying dimension and buying achievement dimension, meanwhile hedonic buying motivation consist of buying enjoyment dimension, dimension of buying satisfaction, dimension of buying idea, buying to aesthetics, roll shopping, and social shopping situation. Avello et al (2010) showed that different female demographic can have different buying motivation. Individual motivation can reflect the type of buying, whether it includes hedonic buying or not.

Koca, Vural, and Koc (2013) revealed that hedonic behavior is created due to some factors, which are demographic, internal factor, and external factor. Internal factor consists of personality, popularity, prestige, and desire to look differently. Meanwhile external factor consists of comfort, duration of use, fashion, and money value. In general, hedonic behavior is defined as people behavior in reflecting their life to find pleasure and involved emotion. The study of Bakirtas and Divanoglu (2013) showed that buying value of consumer consists of hedonic shopping value and utilitarian shopping value. The trait of hedonic is the expectation of fun and happiness from buying activity. Hedonic buying value will create hedonic buying on consumer. The value as the behavior foundation is indicated by buying that is hedonic buying. Hedonic buying which is conducted continuously will negatively impact individual, one of which led to the individual's wasteful. Meanwhile, in daily life individual interacts with the environment and such interactions produce a variety of things that can affect either directly or indirectly. The research showed that hedonic buying value gives negative influence on hedonic buying. Therefore, the hypotheses of this research are as follows:

H1 : There is a significant difference of value between male and female students.

$\mathrm{H} 2$ : There is a significant difference of hedonic buying between male and female students.

H3 : There is a significant influence of value on hedonic buying.

H4 : There is a significant influence of reference group on hedonic buying. 


\section{Method}

\section{Participants}

This research was conducted in Bogor Regency, Dramaga Sub-Districts, Bogor Agricultural University (IPB). The design of this research was cross sectional study. The determination of research location was done by convenience sampling method. Population of this research was students of Bogor Agricultural University at second, fourth, and sixth semester on 2014/2015 academic period. Total population of this research was 10.879 students. The selection of research sample was conducted with proportional random sampling based on sub-population from nine faculties in IPB. Data of active IPB students at second, fourth, and sixth semester on 2014/2015 academic period was collected from Directory Administration of Bogor Agricultural University. Sample was determined based on agreement to fill the questionnaire given. Total sample of this research was determined by Slovin formulation (Umar, 2005) with 7 percent of standard error resulting 205 samples.

\section{Measures}

Research data included: (1) student characteristics (age, gender, and monthly allowance); (2) value; (3) reference group; and (4) hedonic buying. Data were collected through interview using structured questionnaire and supported by in-depth interview on some samples.

Value was measured using the modified Multi-Item List of Values (MILOV) (Herche, 1994, Bearden and Netemeyer, 1999). There were nine dimensions, but this study focused on only four dimensions: well-respected dimension, self-fulfillment dimension, excitement dimension, and fun and enjoyment dimension with 17 statements using four assessment scales ( 1 = strongly disagree, $2=$ disagree, $3=$ agree, $4=$ strongly agree). Four dimension of value was determined based on regression analysis from nine of values and only four dimensions that influenced hedonic buying. Reference group instrument was developed by Permatahati (2013) used to identify the role of reference group (family, friend or relative, neighbor, celebrity, key figure, etc) and to identify the reference group with the most dominant role in influencing individual to do buying the most. Hedonic buying instrument was developed by Guler (2008) and Tauber (1972), as cited in Guido (2006) with 22 statements using four assessment scales $(1=$ strongly disagree, 2 = disagree, $3=$ agree, $4=$ strongly agree).

\section{Analysis}

A test was conducted to verify the validity and reliability the research instrument. The Cronbach's alpha of value variable was 0.742 and 17 items were valid. The Cronbach's alpha of hedonic buying variable was 0.890 with 22 valid items. Microsoft Excel for Windows and Statistical Package for Social Science (SPSS) 16 were used to analyze research data. Data obtained was scored and transformed into a scale of 0 to 100. Statistical analysis that is used in this study was descriptive and inferential analysis. Descriptive analyses were frequency, mean, maximum, minimum, and deviation standard while inferential analyses were Independent Sample T-test and multiple regression analysis. Classic assumption verification was carried out by 
analyzing normality, multi collinearity, heteroskedasticity, and autocorrelation test before conducting multiple regression analysis (Ghozali, 2011).

\section{Result}

\section{Student Characteristics}

Based on student gender, more than half of the students $(61.5 \%)$ were female, and 38.5 percent of the students were male. The student age ranged from 18 until 22 years old. The highest percentage of age was 20 years old with 35.5 percent of male and 45.1 percent of female. The average of student age was 19.9 years old.

Students' monthly allowance ranged from Rp400.000 until Rp4.000.000. The highest percentage of male students' monthly allowance was higher than Rp1.000.000 with the average of Rp1.145.569.6. Meanwhile, the highest percentage of female's monthly allowance was between Rp800.000 and Rp1.000.000 (50\%) and the average was Rp1.054.365.1. The highest percentage monthly allowance of students was between Rp800.000 and Rp1.000.000 (42.8\%) with the average was Rp1.089.512.2.

\section{Value}

Table 1 shows the average score of student value based on four value dimensions. Both male and female were categorized into high level $(50<$ score $\leq 75)$. Categorization level of value was determined based on score of value which then was divided into four categories. Based on those dimensions, only excitement dimension which showed significantly difference $(\mathrm{p}<0.05)$ between male and female. Based on total average of value, both male and female were categorized into high level $(50<$ score $\leq 75)$.

Table 1 The average score of students value

\begin{tabular}{lccc}
\hline Value dimensions & Male $(\mathrm{n}=79)$ & Female $(\mathrm{n}=126)$ & T-test $(\mathrm{p}$-value $)$ \\
\hline Excitement & 65.0 & 60.3 & $0.019^{*}$ \\
Fun and Enjoyment & 68.6 & 66.5 & 0.375 \\
Being Well-Respected & 54.4 & 55.8 & 0.521 \\
Self-Fulfillment & 61.4 & 72.0 & 0.740 \\
\hline Total value & 63.5 & 62.4 & 0.430 \\
\hline
\end{tabular}

Note. $(*)$ significant at $\mathrm{p}<0.05$

\section{Reference Group}

Reference group is individual or group of people around individual's environment, both directly and indirectly communicating with each other and their presence gives influence in buying a product. All students revealed that they received direct and indirect influence from their reference group. The students were asked to mention one of their reference groups that gave the most important role. Table 2 shows the primary reference group that has the most influence on buying. Family was the most important reference group that gave important influences to do buying with 63.7 percent, and the rest 36.2 percent was influenced by friend, celebrities, and other reference groups. 
Table 2 Distribution primary reference group of students

\begin{tabular}{lccc}
\hline Primary Reference Group & Male $(\mathrm{n}=79)$ & Female $(\mathrm{n}=126)$ & Total $(\mathrm{n}=205)$ \\
\hline Family & 54.4 & 73.0 & 63.7 \\
Friend/best friend & 36.7 & 23.0 & 29.9 \\
Celebrities & 5.1 & 4.0 & 4.5 \\
Others* & 3.8 & 0.0 & 1.9 \\
\hline
\end{tabular}

Note. $(*)$ neighbour, key figures, mass media

\section{Hedonic Buying}

Based on the category of hedonic buying, the biggest percentage of students was in low level with percentage of male was 62.2 percent and 59.5 percent of female, but there remained 2.5 percent of male and 3.2 percent of female in very high level. Level of hedonic buying was determined by score of hedonic buying item. Total score of hedonic buying was divided into four levels: very low, low, high, and very high. The average score of male students' hedonic buying was 42.1 percent and 47.4 percent of female students. Table 3 shows there was significant difference of hedonic buying $(p=0.009)$ between male and female students.

Table 3 Distribution hedonic buying of students

\begin{tabular}{lccc}
\hline Hedonic buying category & Male $(\mathrm{n}=79)$ & Female $(\mathrm{n}=126)$ & Total $(\mathrm{n}=205)$ \\
\hline Very low $($ score $\leq 25)$ & 13.8 & 4.8 & 9.3 \\
Low $(25<$ score $\leq 50)$ & 62.2 & 59.5 & 60.8 \\
High $(50<$ score $\leq 75)$ & 21.5 & 32.5 & 27.0 \\
Very high $($ score $>75)$ & 2.5 & 3.2 & 2.9 \\
\hline Mean \pm SD & $42.1 \pm 15.29$ & $47.4 \pm 13.25$ & $38.0 \pm 12.3$ \\
Min-max & $6.1-81.8$ & $16.7-83.3$ & $2.3-70.5$ \\
t-test $(\mathrm{p}$-value $)$ & & $0.009 * *$ & \\
\hline
\end{tabular}

Note. $(*)$ significant at $\mathrm{p}<0.05$

The items of hedonic buying were categorized into three parts based on fulfill involvement: emotion, physical, and social. Hedonic buying fulfilling involvement aimed to get what the things individual wanted. Emotion aspect in hedonic buying was caused by individual internal factor that tended to find the happiness and excitement from excused buying. If emotion aspect of students was high, it indicated the hedonic buying done to find the happiness and excitement was high as well. There were some items that involved social aspect, reflected by hedonic buying which was done due to stimulus from people around. If social aspect of students in hedonic buying was high, it indicated the students often did hedonic buying because of the influence of people around. Besides, there was another form of hedonic buying involving physical aspect and combination between physical and emotion aspects. If physical aspect in hedonic buying was high, it indicates activities in hedonic buying such as walking around to find the product was also high. If the combination between physical aspect and emotion aspect was highly characterized by physical activity involvement that gave pleasure to individual, it could make physical activity fun. Based on four aspects in hedonic buying, most of hedonic buying items involved emotion aspect. It was shown with internal aspect that can be mainspring for individual to do hedonic buying. 


\section{Factors That Influence Hedonic Buying}

The result of normality test showed that the data of this research spreaded along the diagonal line. It indicated that variables of this research had normal distribution and the normality test was fulfilled. The results assumption of multi collinearity test showed tolerance value over 0.1 and Variance Inflation Factor (VIF) value under 10. It means that the model has been fulfilled the assumption of non multi collinearity. It could be concluded that the variables of this research was fulfilled of homoskedacity. It was shown with scatterplot result from the regression analysis that indicated the error distribution spreading at zero. Durbin-Watson value in this research was nearly +2 , showed that autocorrelation had free model (Table 4).

Adjusted $R^{2}$ value of regression model was 0.359 meaning that 35.9 percent of the independent variables in this research was influenced by hedonic buying while 64.1 percent else was influenced by others factors that did not include in this research. Patel and Sharma (2009) and Avello et al (2010) revealed that other factors that influences hedonic buying is motivation. According to Alba and Williams (2012), other factor that influenced hedonic buying was individual perception. Meanwhile, according to Pattipeilohy, Rofiaty, and Idrus (2013) the factor that influenced hedonic buying were situational factor contained money and time availability. Based on the factors predicted hedonic buying, the results of regression analysis showed that only the reference group did not significantly influence hedonic buying. Linear regression formula in this research was as follows:

$$
\begin{gathered}
Y=-12.744+6.420 D_{1}+7.218 X_{1}+0.288 X_{2}+0.169 X_{3}+0.160 X_{4}+0.141 X_{5+} 0.762 \\
D_{2}+\varepsilon
\end{gathered}
$$

It indicates that if the student gender was female, hedonic buying would increase by 6.420 point. If student's monthly allowance increased up to Rp1 per month, hedonic buying would increase by 7.218 point. The increase one score of well-respected value dimension would increase hedonic buying by 0.288 point while the increase one score of self-fulfillment value dimension would increase hedonic buying by 0.169 point. The increase of one score of excitement value dimension would increase hedonic buying by 0.160 point and the increase one score of fun and enjoyment value dimension would increase hedonic buying by 0.141 point. 
Table 4 Factors influencing hedonic buying

\begin{tabular}{|c|c|c|c|c|c|c|}
\hline \multirow[t]{2}{*}{ Independent variables } & \multirow{2}{*}{$\begin{array}{l}\text { Unstandardized } \\
\text { Coefficients } \\
\text { (B) }\end{array}$} & \multirow{2}{*}{$\begin{array}{l}\text { Standardized } \\
\text { Coefficients } \\
\text { (Beta) }\end{array}$} & \multirow[t]{2}{*}{$\mathrm{t}$} & \multirow[t]{2}{*}{ Sig. } & \multicolumn{2}{|c|}{$\begin{array}{l}\text { Collinearity } \\
\text { Statistics }\end{array}$} \\
\hline & & & & & Tolerence & VIF \\
\hline (Constant) & -12.744 & & -2.231 & 0.027 & & \\
\hline \multicolumn{7}{|l|}{ Individual characteristics } \\
\hline $\begin{array}{l}\text { Gender }(0=\text { male; } \\
1=\text { female })\end{array}$ & 6.420 & 0.219 & 3.729 & $0.000 * *$ & 0.908 & 1.101 \\
\hline $\begin{array}{l}\text { Monthly allowance } \\
\text { (Rp/month) }\end{array}$ & 7.218 & 0.245 & 4.298 & $0.000 * *$ & 0.964 & 1.037 \\
\hline \multicolumn{7}{|l|}{ Value } \\
\hline $\begin{array}{l}\text { Well-Respected } \\
\text { (score) }\end{array}$ & 0.288 & 0.289 & 4.713 & $0.000 * *$ & 0.838 & 1.193 \\
\hline $\begin{array}{l}\text { Self-Fulfillment } \\
\text { (score) }\end{array}$ & 0.169 & 0.139 & 2.070 & $0.040 *$ & 0.693 & 1.443 \\
\hline Excitement (score) & 0.160 & 0.150 & 2.350 & $0.020 *$ & 0.768 & 1.302 \\
\hline $\begin{array}{l}\text { Fun and Enjoyment } \\
\text { (score) }\end{array}$ & 0.141 & 0.157 & 2.486 & $0.014^{*}$ & 0.786 & 1.272 \\
\hline $\begin{array}{l}\text { Peer group }(0=\text { non } \\
\text { family; } 1=\text { family })\end{array}$ & 0.762 & 0.025 & 0.436 & 0.664 & 0.934 & 1.071 \\
\hline $\mathrm{F}$ & \multicolumn{6}{|c|}{$17.327(0.000)$} \\
\hline Durbin-Watson & \multirow{2}{*}{\multicolumn{6}{|c|}{$\begin{array}{l}1.789 \\
0.359\end{array}$}} \\
\hline Adjusted $\mathrm{R}^{2}$ & & & & & & \\
\hline
\end{tabular}

Note. $(* *)$ significant at $\mathrm{p}<0.01 ;(*)$ significant at $\mathrm{p}<0.05$

\section{Discussion}

The aim of this research was to identify the differences in value and the hedonic buying of young consumer (represented by college students) and to analyze the effect of value and reference group on hedonic buying on young consumer. Based on student characteristics, there was no significant difference of students' age and monthly allowance. The students' age was between 18 and 21 years old which according to Hayta (2013) is categorized into young consumer. Value consisted of nine dimensions: security, self-respected, being well-respected, self-fulfillment, sense of belonging, excitement, fun and enjoyment, warm relationships with others, and a sense of accomplishment that can be measured with nine dimensions of MILOV (Nonis and Swift, 2001). This research focused on four dimensions: well-respected, self-fulfillment, excitement, and fun and enjoyment. From these dimensions, excitement value dimension was the only one that showed significant difference $(\mathrm{p}<0.05)$ between male and female. Excitement value dimension is value that can be shown with attitude to pursue daily life happiness. It was reflected in value item "consider her/his self a thrillseeker" which had significant difference between male and female. This item showed that the average of male tended to agree more than female. Based on in-depth interview with one of the male students, he said that he was not purposively done the things that made him to be a thrill-seeker, but he tried to make people recognize him with that trait in himself. Based on this difference, it can be concluded that $\mathrm{H} 1$ at first hypothesis (hypothesis number 1) in this research (there was a significant difference in value between male and female) was partially supported.

Based on hedonic buying of students, there was significant difference $(\mathrm{p}<0.01)$ of hedonic buying between male and female, so it can be concluded that $\mathrm{H} 1$ at second 
hypothesis (hypothesis number 2) in this research can be accepted. The significant difference showed in one of hedonic buying questionnaire item "buying can relieving distress". The female students tended to agree with this statement. It was different with male students who thought that buying was a complicated thing, so male students had already had a plan before buying something. Besides, there was a significant difference in hedonic buying item "enjoying to walk, see, but not buying anything" between male and female. Based on in-depth interview with some of female students, they sometimes did windows shopping, but it made them want to buy, because they were attracted by some products. Conversely, male students kept enjoying to do all of the activities even without buying anything. The hedonic buying item "the new shopping center was interesting place to visit" had significant difference between male and female, even most of them agreed.

The regression analysis in this research was done to show factors that influenced hedonic buying. According to Luo and James' study (2013), internal and external factors could influence individual buying. The internal factors in this research were individual characterstic and value while the external factor was reference group. The result of regression analysis showed that gender significantly influenced hedonic buying; female students tended to do more hedonic buying than male students. This result supported by the study of Avello et al (2010) that hedonic buying was done more by female, even every female had different reasons to do hedonic buying. It is reflected by in-depth interview with two different students:

"I usually go shopping or buying something because of mood, or suddenly because of my friends, I follow her finally."

"I usually buy something if there is a new thing, because I am a girl, so I like to try new thing."

Besides gender, monthly allowance of students significantly positively influenced hedonic buying. It is supported by Pattipeilohy, Rofiaty, and Idrus's research (2013) that money and time availability as mediator could influence individuals' hedonic buying. Every one had different way to spend their hedonic buying, such as visit mall to buy a product or windows shopping only. Based on in-depth interview with one of the students, money availability could influence buying:

"I love to collect some necklaces and shoes, but I can't do it every time, because the price of shoes is expensive. I buy necklaces by online shop because it is simpler and it is not too expensive like shoes. I usually try to save my money before, so I can buy shoes at the end of the month from the saving..."

The average value based on four dimension of value, male and female students were categorized into high level $(50<$ score $\leq 75)$ and the result of this research answered H3 stated "there was a significant influence of value on hedonic buying". It is in line with Guler's research (2014) that some individuals' values could influence people's hedonic consumption that assumed buying in this research. The value of self-respect dimension is an effort by someone to keep high status among people around and caring about respond given by environment to themselves. The more people want to be respected, the higher value of self-respect dimension. In-depth interview with one of student said that: 
"... I usually hang out with my friends or my girlfriend, but my girlfriend and I usually hang out in better place. I don't want her to think that I don't want to spend money on her..."

The meaning of fun and enjoyment dimension value is the thing that people get to have self-pleasure based on doing something, like two students said:

“...I buy something because I collect the things surely, although I can't get benefit actually, but it can be regretful if I do not buy the thing..."

“...I rarely buy some things, but I deliberately save my money to buy chip for games online...”

Self-fulfillment dimension value is reflected by attitude that always tries to fulfill thing they want. Based on value of self-fulfillment dimension, the higher score people get on self-fulfillment item, the more they agree to fulfill their want and need. One of students said:

"...need is the thing that must be fulfilled, because it can be a spirit for ourselves to do work and any activity. So it can be called as the gift for ownself..."

Reference group gives important role to individual to do anything, one of which is to do buying. Family was the most important reference group. The roles of family were financial support, norms, rules or models. The other reference groups having important role was friend or relative. Although young consumers have good relationship with their family, the influence of reference group also strong because they spend most of their time with their friends (Alpiani, 2014). Based on in-depth interview, most students who lived separately from their family, friends or relative were the people with nearly the same way of thinking with them, so the average of them consider the opinion more and suggestion from their friends than their family.

"My parents have important role surely, because I get money from them, but I more consider my friend's opinion more. But, if the opinion from my friend does not match with my family, I usually cancel to buy something."

The result of this research showed that in daily activities including buying, reference group had important role for individual directly and indirectly, but the reference group did not give significant influence on hedonic buying. This research showed that $\mathrm{H} 4$ (there was a significant influence of reference group on hedonic buying) was rejected. This is contradicting with Permatahati's research (2013) but supports Istikhomah's research (2013) stated that reference group influenced individual buying. It showed that reference group had important role for individual, but it was not always the reference to do particular buying. Based on in-depth interview, some students agreed that reference group had important role for them. The roles can be a comparator or model with themselves, given the rule and norms in life, but buying is followed by intention more from themselves. The intention gives conclusion whether they buy a product or not.

The result of this research also showed that only value that significantly 
influenced hedonic buying with well-respected dimension was the most influence. Meanwhile, reference group had important roles, such as to give opinion and information, but the regression analysis showed that the reference group did not significantly influence hedonic buying. The aim of this research was not to test perception and motivation of students to do buying before. The people perception about product can be influenced by many things, it can be different for one another (Alba and Williams, 2012). Buying that considered hedonic by some people, might be considered as well by others. Some others considered buying as different motivation by others included hedonic buying. The same things also said by Patel and Sharma (2009) and Avello et al (2010), so it is important to know the motivation of people in doing hedonic buying.

\section{Conclusion and Recommendation}

\section{Conclusion}

Value dimension which consists of well-respect dimension, self-fulfillment dimension, excitement dimension, and fun and enjoyment dimension was considered high. Reference group of students that had primary role to buy was family. Generally, the students of this research were in low category of hedonic buying. The result of independent sample t-test based on gender showed that only value of excitement dimension and hedonic buying which were significantly different between male and female. There was a significant positive influence between individual characteristics (gender and monthly allowance) and four dimensions of value towards hedonic buying. It means female students had more tendencies to do hedonic buying than male students. The higher students' monthly allowance, the higher probability do hedonic buying. If the score of individual value (excitement value dimension, fun and enjoyment value dimension, being well-respected dimension, and self-fulfillment dimension) was high, it pushed individual to do hedonic buying.

\section{Recommendation}

This study found that value positively and significantly influenced hedonic buying. Moreover, based on students' answer, family was primary reference group that had important role in giving influence. Value significantly influenced hedonic buying in high category. The importance of family role in daily live is expected to lower values that influence individual hedonic buying, so that hedonic buying can be minimized, since the effect in long term of hedonic buying are consumptive and extravagant. Individual ought to know and make a priority of need over desire, it is important to realize one of traits of smart consumer. Further research is expected to test perception and motivation of students before doing hedonic buying. The future research is expected to classify hedonic buying specifically. 


\section{References}

Alba, J. W., \& Williams, E. F. (2012). Pleasure principles: A review of research on hedonic consumption. Journal of Consumer Psychology, 23(1), 2-18. doi: org/10.1016/j.jcps.2012.07.003.

Alpiani, A. (2014). Pengaruh pengasuhan orang tua dan teman sebaya terhadap perilaku konsumi napza pada remaja [The influence of parenting style and peer groups on drugs consumption behavior of adolescent] (Undergraduate thesis). Retrieved from http://repository.ipb.ac.id/bitstream/handle/123456789/71935/I14aal.pdf?sequence= $1 \&$ isAllowed=y.

Avello, M., Gavilan, D., Blasco, F., \& Abril, C. (2010). Hedonic buying motivation and time-style. The International Journal of Management and Business, 1(1), 128-155. Retrieved from http://www.iamb.net/IJMB/journal/Vol_1/IJMB_Vol_1_Avello.pdf.

Bakirtas, H., \& Divanoglu, S. U. (2013). The effect of hedonic shopping motivation on consumer satisfaction and consumer loyalty. International Journal of Asian Social Science, 3(7), 1522-1534. Retrieved from http://www.aessweb.com/pdffiles/ijass\%203(7),\%201522-1534.pdf.

Bearden, W. O., \& Netemeyer, R. G. (1999). Handbook of Marketing Scales: Multi-item Measures for Marketing and Consumer Behavior Research (2nd ed.). California, CA: Sage Publications.

Carstensen, L. L., Gross, J. J., Skorpen, C. G., Tsai, J, \& Hsu, A. Y. C. (1997). Emotion and aging: Experience, expression, and control. Journal of Psychology and Aging, 12(4), 590-599. Retrieved from http://spl.stanford.edu/pdfs/Pre\%201998/1997\%20Gross.pdf.

Dewantara, M. M., \& Simanjuntak, M. (2014). The effect of knowledge, religiosity, and attitude on halal label reading behavior of undergraduate students. ASEAN Marketing Journal, 6(2), 65-67. Retrieved from http://journal.ui.ac.id/index.php/amj/article/view/4216/3160.

Escalas, J. E., \& Bettman, J. R. (2003). You are what they eat: The influence of reference groups on consumers' connections to brands. Journal of Consumer Psychology, 13(3), 339-348. Retrieved from https://faculty.fuqua.duke.edu/ jrb12/bio/Jim/53.pdf.

Ghozali, I. (2011). Aplikasi Analisis Multivariate dengan Program IBM SPSS 19 [Multivariate Analysis Applications with IBM SPSS 19 Program]. Semarang, Indonesia: Badan Penerbit Universitas Diponegoro.

Guido, G. (2006). Shopping motives, big five factors, and the hedonic/utilitarian shopping value: An integration and factorial study. Innovative Marketing Journal, 2(2), 57-67. Retrieved from http://businessperspectives.org/journals_free/im/2006/im_en_2006_02_Guido.pdf.

Guler, Y. B. (2014). Values and hedonic consumption behavior: A field research in Kirikkale. Asian Journal of Empirical Research, 4(3), 159-171. Retrieved from http://www.aessweb.com/pdf-files/1-64-4(3)2014-AJER-159-171.pdf.

Hayta, A. B. (2013). A study on the effects of social media on young consumers' buying behavior. European Journal of Research on Education, 65-74. Retrieved from http://iassr2.org/rs/010408.pdf. 
Herche, J. (1994). Measuring Social Values: A multi-item Adaptation to the List of Values (MILOV) (Working Paper Report Number 94-101). Cambridge, MA: Marketing Science Institute.

Istikhomah, E. (2013). Pengaruh kelompok acuan dan pengetahuan terhadap minat beli produk pangan IPB pada mahasiswa program sarjana [The effects of reference groups and knowledge toward intention to buy IPB's food products on undergraduate student] (Undergraduate thesis). Retrieved from http://repository.ipb.ac.id/bitstream/handle/123456789/63141/I13eis.pdf?sequence= $1 \&$ isAllowed=y.

Koca, E., Vural, T., \& Koc, F. (2013). An evaluation of consumer tendencies towards hedonistic shopping for clothes. European Journal of Research on Education, Special Issue: Human Resource Management, 54-64. Retrieved from http://iassr2.org/rs/010407.pdf.

Luo, Q., \& James, P. T. J. (2013). Influences on the buying behavior of purchasing commercial housing in Nanning city of Guangxi Province, China, Journal of Management and Marketing Research, 12, 1-11. Retrieved from http://www.aabri.com/manuscripts/121308.pdf.

Mahdi, M. (2014). Peranan nilai adat dalam modernisasi di Kampung Ciptagelar Cisolok Sukabumi [The Role of indegenious value in modernization at Ciptagelar Village, Cisolok, Sukabumi] (Undergraduate thesis). Retrieved from http://repository.ipb.ac.id/bitstream/handle/123456789/73478/I14mma.pdf?sequence $=1 \&$ isAllowed $=\mathrm{y}$.

Nonis, S., \& Swift, C. O. (2001). Personal value profiles and ethical business decisions. Journal of Education for Business, 251-256.

Nurjanah, S. (2010). Perilaku Ekonomi [Economic Behaviour] [PDF]. Retrieved from http://sitinurjanah.net/attachments/article/83/Perilaku\%20ekonomi.pdf.

Patel, V., \& Sharma, M. (2009). Consumer's motivation to shop in shopping malls: A study of Indian shoppers. Journal: Advances in Consumer Research, 8, 285-290. Retrieved from http://www.acrwebsite.org/volumes/ap08/ap_2009_vol8_134.pdf.

Pattipeilohy, V. R., Rofiaty, \& Idrus, M. S. (2013). The influence of the availability of money and time, fashion involvement, hedonic consumption tendency and positive emotions towards impulsive buying behavior in Ambon City. Journal of Business and Behavioral Sciences, 3(8), 36-49. Retrieved from http://cprenet.com/uploads/archive/IJBBS_12-1268.pdf.

Permatahati, D. I. (2013). Pengaruh gaya hidup, kelompok acuan, dan sikap terhadap pembelian produk makanan kemasan (Kasus: Ibu rumah tangga di wilayah perkotaan dan perdesaan Bogor) [Lifestyle, reference group, and attitude purchasing food packaged products (Case study: Housewives in Bogor rural and urban areas)] (Undergraduate thesis). Rertrived from http://repository.ipb.ac.id/bitstream/handle/123456789/67380/I13dip.pdf?sequence= $1 \&$ isAllowed=y.

Pinasthika, A. W. K. (2010). Hubungan minat, motif, dan pola menonton sinetron di televisi dengan perilaku hedonis remaja (Kasus SMA Negeri dan Swasta Kota Bogor) [Relationships between interests, motives and patterns to watch soap operas on television with hedonic behavior of adolescents (Case of Public and Private High Schools, Bogor City)] (Undergraduate thesis). Retrieved from http://repository.ipb.ac.id/bitstream/handle/123456789/60030/I10awk.pdf?sequence $=1 \&$ isAllowed $=\mathrm{y}$. 
Sarkar, A. (2011). Impact of utilitarian and hedonic shopping values and individual's perceived benefits and risks in online shopping. International Management Review, $7(1), 58-65$.

Sumarwan, U. (2011). Perilaku Konsumen: Teori dan Penerapannya dalam Pemasaran [Consumer Behavior: Theory and Practice in Marketing]. Jakarta, Indonesia: PT Ghalia Indonesia.

Umar, H. (2005). Metode Penelitian untuk Skripsi dan Tesis Bisnis [Research Method for Business Undergraduate and Master Theses]. Jakarta, Indonesia: Raja Grafindo Persada.

Veenhoven, R. (2003). Hedonism and happiness. Journal of Happiness Studies, 4, 437457. 